\title{
EVALUASI MANAJEMEN PROYEK
}

\author{
Suryanto $^{1}$; Sanyoto Gondodiyoto² ${ }^{2}$ Desi N.I ${ }^{3}$;ryanto $^{4}$; Elis Triana ${ }^{5}$ \\ ${ }^{2}$ Sekolah Tinggi Akuntansi Negara \\ Jl. Bintaro Utama Sektor V, Tangerang Selatan Banten - Indonesia 15223 \\ 1,3,4,5 Jurusan Komputerisasi Akuntansi, Fakultas Ilmu Komputer, Universitas Bina Nusantara, \\ Jln. K.H. Syahdan No.9, Palmerah, Jakarta Barat 11480 \\ suryanto1865@yahoo.com
}

\begin{abstract}
The purpose of this study was to evaluate the project management and make suggestions to the problems being faced by the company. Many companies or individuals working on a project basis (project based), but many of those who do not manage the project well, even with no management at all and let the project flow as it is. Therefore, it needs a proper guidance and methods to support a project management information system. The research method used is the method of data collection, covering literature from books, articles from the internet, and study the documentation to PT ACM through direct interviews with the parties concerned with the project. The data analysis technique used is based on the 9 knowledge areas and 5 stages in project management. The results are the company's project is proposed to be closed (closing) so as not to increase corporate spending on the project. The conclusion of this scientific work is a project run by the 2 parties have a higher risk of failure.
\end{abstract}

Keywords: evaluation, management, project

\section{ABSTRAK}

Tujuan penelitian ini adalah untuk mengevaluasi manajemen proyek dan memberikan usulan terhadap permasalahan yang sedang dihadapi oleh perusahaan. Banyak perusahaan atau individu yang bekerja berdasarkan proyek (project based), tetapi banyak dari mereka yang tidak mengelola proyek tersebut dengan baik, bahkan tanpa pengelolaan sama sekali dan membiarkan proyek tersebut mengalir apa adanya. Maka dari itu, sangat diperlukan suatu panduan dan metode yang tepat untuk mendukung pengelolaan suatu proyek sistem informasi. Metode penelitian yang digunakan adalah dengan metode pengumpulan data, meliputi studi pustaka dari buku-buku, artikel dari internet, dan studi dokumentasi ke PT ACM melalui wawancara secara langsung dengan pihak-pihak yang bersangkutan dengan proyek. Teknik analisis data yang digunakan adalah berdasarkan 9 area pengetahuan dan 5 tahapan dalam manajemen proyek. Hasil yang dicapai adalah proyek pada perusahaan diusulkan untuk ditutup (closing) agar tidakmenambah pengeluaran perusahaan pada proyek tersebut. Kesimpulan dari karya ilmiah ini adalah sebuah proyek yang dijalankan oleh 2 pihak memiliki risiko kegagalan lebih tinggi.

Kata kunci: evaluasi, manajemen, proyek

\section{PENDAHULUAN}

Dewasa ini, dunia bisnis dihadapkan pada pola persaingan yang demikian ketat, permasalahan yang semakin kompleks, dan dinamika perubahan sistem bisnis yang sangat cepat. Faktor utama yang menciptakan kondisi ini antara lain adalah kemajuan yang pesat di bidang teknologi informasi dan semakin meluasnya pemberlakuan sistem pasar bebas di seluruh dunia. Kecepatan dalam mendapatkan informasi yang up to date dan proses bisnis harus dengan segera dapat memenuhi kebutuhan konsumen merupakan salah satu faktor yang penting dalam menunjang kesuksesan suatu perusahaan.

Banyak perusahaan telah mengakui pentingnya menerapkan sistem informasi yang terintegrasi di perusahaan mereka, maka tidak sedikit dari mereka yang mulai menjamah teknik manajemen yang baru, yaitu manajemen proyek untuk sistem informasi, di mana merupakan suatu cabang dari ilmu manajemen yang digunakan untuk mengestimasi waktu, sumber daya, dan biaya serta risiko yang dapat ditimbulkan dari pelaksanaan suatu proyek sistem informasi. Banyak perusahaan yang memilih untuk menyerahkan pengembangan sistem informasi mereka sepenuhnya ke pihak developer, tapi tidak sedikit juga yang menggunakan outsourcing; salah satunya adalah PT ACM. yang mengembangkan sistem informasi mereka dengan menggunakan outsourcing.
Untuk lebih mengarahkan penulisan dan penyusunan manajemen proyek ini, adapun ruang lingkup yang akan dibahas pada manajemen proyek pada perusahaan adalah evaluasi pengelolaan proyek yang telah dilaksanakan oleh perusahaan serta usulan panduan pengelolaan proyek untuk mengatasi permasalahan yang dihadapi dalam proyek.

Berdasarkan hakikatnya, proyek dapat didefinisikan sebagai "Rangkaian usaha dalam jangka waktu tertentu yang bertujuan untuk menghasilkan sebuah produk atau jasa/ pelayanan unik tertentu, dilaksanakan oleh manusia dengan memanfaatkan berbagai sumber daya, melalui rangkaian proses perencanaan, eksekusi, dan kontrol" (K.C. Chan, 2004: 68). Sedangkan Schwalbe (2004) memaparkan proyek sebagai suatu usaha yang bersifat sementara untuk menghasilkan suatu produk atau layanan yang unik. Hal yang patut dicatat sehubungan dengan definisi proyek tersebut adalah, bahwa (1) Proyek memiliki jangka waktu tertentu, yang berarti bahwa rangkaian aktivitas tersebut memiliki titik mulai dan titik selesai yang pasti (ditargetkan); dan (2) Bersifat unik, yang berarti bahwa tidak ada proyek yang menghasilkan produk atau jasa/pelayanan yang identik.

Manajemen proyek adalah kegiatan merencanakan, mengorganisasikan, mengarahkan, dan mengendalikan sumber daya organisasi perusahaan untuk mencapai tujuan dalam waktu tertentu, dengan sumbe rdaya tertentu (Budi Sentosa, 2003: 3). Manajemen proyek mempergunakan 
personel perusahaan untuk ditempatkan pada tugas tertentu dalam proyek.

Schwalbe(2004:71)mengemukakan dalammanajemen proyek, inisiasi adalah proses mengenal dan memulai sebuah proyek baru atau fase proyek. Sedangkan K.C. Chan (2004: 97) menyatakan bahwa inisiasi merupakan aktivitas yang berkaitan dengan Project Scope Management, yaitu sebuah proses mendefinisikan ruang lingkup proyek yang ingin dikerjakan. Seluruh knowledge area membutuhkan aktivitas perencanaan karena sangat erat berkaitan dengan kebutuhan dan alokasi sumber daya yang dibutuhkan di dalam proyek. Tujuan utama dari perencanaan proyek adalah sebagai panduan dalam pelaksanaan proyek (Schwalbe, 2004: 78). Untuk itu rencana yang dibuat harus realitas dan berguna. Untuk menciptakan rencana yang realitas dan berguna, cukup banyak waktu dan usaha yang harus dilibatkan dalam proses perencanaan dan pengetahuan orang dalam melakukan kebutuhan kerja untuk merencanakan pekerjaan.

Executing merupakan aktivitas di mana pekerjaan yang telah digariskan di dalam proyek dilaksanakan atau diterapkan (K.C. Chan, 2004: 99). Produk dari proyek dihasilkan selama eksekusi proyek, dan biasanya memakan banyak sumber daya untuk diselesaikan. Pengontrolan adalah membandingkan kemajuan proyek dengan objektif proyek, pengawasan penyimpanan dari rencana, dan mengambil tindakan korektif untuk menyesuaikan kemajuan dengan rencana. Proses penutupan proyek meliputi kegiatan untuk mendapatkan penerimaan pemegang saham dan pelanggan dari produk akhir (Schwalbe, 2004: 96-97). Hal ini meliputi verifikasi terhadap semua pekerjaan yang sudah diselesaikan, dan menyangkut audit proyek.

Pembatalan proyek dapat dilakukan dengan 2 cara, yaitu pemusnahan langsung (extinction) dan starvation, yakni mengakhiri proyek dengan cara ini sangat sulit dan biasanya diselesaikan ketika organisasi tidak bersedia mengakui proyek gagal. Sembilan aspek pengetahuan (Project Management Knowledge Areas) berdasarkan Schwalbe (2004: 106-107), yaitu manajemen integritas proyek meliputi proses yang terlibat di dalam mengkoordinasi semua area pengetahuan manajemen proyek lain melalui daur hidup proyek. Jadi, hal ini digunakan untuk meyakinkan bahwa semua elemen dari proyek digunakan bersama pada waktu yang tepat untuk menyukseskan suatu proyek.

Ruang lingkup mewakili semua kinerja yang terlibat dalam menciptakan produk, dari proyek dan proses untuk menciptakan proyek tersebut. Sedangkan ruang lingkup proyek mencakup semua proses yang terlibat dalam pendefinisian dan pengaturan mengenai apa yang termasuk atau tidak di dalam proyek. Ada beberapa pendekatan yang dapat digunakan untuk membangun WBS, yaitu (1) Menggunakan guidelines. Jika pendekatan untuk mengembangkan suatu WBS masih berjalan, maka sangat penting untuk mengikuti guidelines tersebut; (2) The analogy approach. Di dalam pendekatan analogi, digunakan WBS proyek yang sudah-sudah yang mirip sebagai tahap untuk mulai. Beberapa organisasi menyimpan WBS dan dokumen lain dalam file untuk membantu orang yang bekerja dalam proyek. Dengan melihat contoh dari WBS proyek yang mirip, akan memungkinkan untuk mengerti cara yang berbeda untuk membuat sebuah WBS; (3) The top-down dan bottom-up approach. Untuk menggunakan pendekatan top-down, mulai dengan perihal yang besar dari proyek dan pecahkan menjadi perihal yang lebih rinci. Proses ini melibatkan proses penyaringan kerja menjadi detail yang lebih besar. Dengan pendekatan bottomup, anggota tim harus mengidentifikasi sebanyak mungkin tugas khusus yang berhubungan dengan proyek. Kemudian, anggota tim akan mengagregasi tugas tersebut dan mengatur mereka menjadi aktivitas yang dirangkum.

Untuk menciptakan WBS yang baik membutuhkan beberapa prinsip, yaitu (1) Sebuah jenis kerja hanya muncul sekali dalam WBS; (2) Content pekerjaan dari sebuah perihal WBS adalah jumlah perihal WBS di bawahnya; (3) Perihal WBS adalah tanggung jawab dari seorang individu, meskipun banyak orang yang bekerja di dalamnya; (4) WBS harus konsisten dengan jalan di mana pekerjaan dilakukan, harus membantu anggota tim dulu dan tujuan lain bila perlu; (5) Anggota tim proyek harus terlibat dalam membangun WBS untuk meyakinkan konsistensi dan buy-in; (6) Setiap perihal WBS harus didokumentasikan untuk meyakinkan pengertian yang akurat mengenai hal yang termasuk dan yang tidak termasuk dalam ruang lingkup kerja; (7) WBS harus sebuah alat yang fleksibiliti untuk mengakomodasi perubahan yang tak terduga, sementara menjaga pengaturan content pekerjaan dalam proyek agar sesuai dengan pernyataan ruang lingkup.

Manajemen waktu proyek secara sederhana didefinisikan sebagai suatu proses yang dibutuhkan untuk meyakinkan pemenuhan waktu dari proyek. Tetapi pencapaian hasil ini tidak sederhana. Penjadwalan proyek bisa digambarkan dengan menggunakan Gantt Charts (Gambar 1). Gantt Charts menyediakan suatu format standar untuk menggambarkan informasi mengenai jadwal proyek, dengan menampilkan kegiatan proyek, jadwal mulai, dan jadwal selesai dalam format kalender. Yang diperlihatkan dalam Gantt Charts adalah hubungan antara aktivitas dan waktu pekerjaannya. Di sini juga dapat dilihat, aktivitas mana yang yang harus mulai dulu dan aktivitas mana yang menyusulnya.

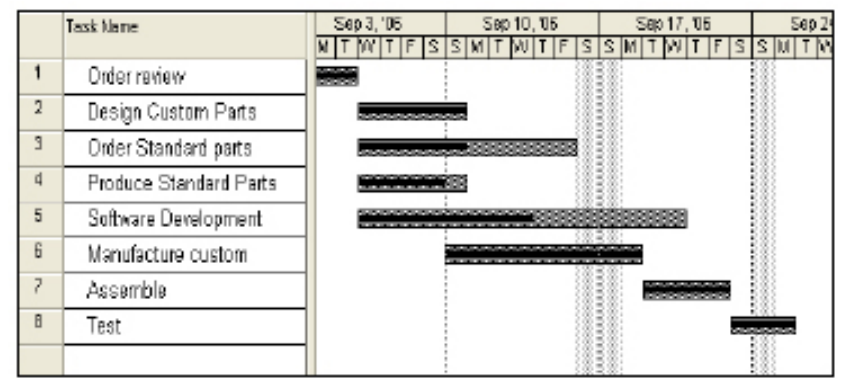

Gambar 1 Gantt Chart

(Sumber: Clifford, 2000: 107)

Manajemen biaya proyek melibatkan proses yang dibutuhkan untuk meyakinkan bahwa proyek terselesaikan dengan anggaran yang dianjurkan. Seorang manajer proyek harus dapat meyakinkan bahwa proyek sudah didefinisikan dengan baik, mempunyai waktu yang akurat dan perkiraan harga, dan mempunyai anggaran yang realitas di mana tim proyek terlibat dalam hal penganjuran tersebut. Merupakan tugas manajer untuk memuaskan stakeholder proyek, sementara melanjutkan penekanan untuk mengurangi dan mengontrol biaya. Kualitas yang dimaksud di sini biasanya memiliki hubungan keterkaitan yang sangat erat dengan sejumlah standar internasional, seperti contohnya adalah memenuhi ISO sebagai panduan sistem manajemen mutu (misalnya dalam pembuatan aplikasi, diperhatikan kaidah baku software engineering yang memenuhi software quality assurance). Dalam berbagai konteks, kualitas kerap pula diartikan sebagai totalitas output yang diharapkan oleh pemrakarsa atau sponsor proyek. Dengan kata lain, mereka yang termasuk di dalam stakeholder proyek mendefinisikan harapan-harapannya terhadap hasil dari proyek yang dikerjakan.

Manajemen sumber daya manusia proyek melibatkan proses yang dibutuhkan untuk melakukan efektifitas dari penggunaan orang yang terlibat dengan proyek. Manajemen sumber daya manusia menyangkut semua stakeholder proyek seperti sponsor, pelanggan, anggota tim proyek, staf pendukung, para penjual yang mendukung proyek, dan lainlain. Tujuan dari manajemen komunikasi proyek adalah untuk meyakinkan waktu dan turunan yang benar, pengumpulan, penyebaran, penyimpanan, dan peletakan dari informasi proyek. 
Manajemen risiko proyek merupakan pengetahuan untuk mengidentifikasikan, menugaskan, dan menanggapi risiko melalui daur hidup proyek dan perhatian dalam memenuhi objektif proyek. Tujuan dari manajemen risiko proyek dapat dilihat dengan meminimalkan potensi risiko sementara memaksimalkan potensi peluang atau pengeluaran. Pengadaan (procurement) proyek mempunyai arti mendapatkan barang dan atau jasa dari sumber daya luar. Keberhasilan dari proyek yang menggunakan sumber daya dari luar perusahaan sering tergantung pada manajemen pengadaan proyek. Manajemen proyek itu sendiri meliputi proses yang dibutuhkan untuk mendapatkan barang atau jasa untuk proyek dari luar.

\section{METODE PENELITIAN}

Untuk mencapai tujuan yang diharapkan, maka penulis menggunakan beberapa metode yang mendukung dan lebih terarah seperti metode penelitian kepustakaan, penelitian lapangan, dan analisis data.

\section{HASIL DAN PEMBAHASAN}

Evaluasi dilakukan dengan tujuan untuk mencoba memberikan masukan kepada perusahaan dalam menghadapi masalah yang dihadapi proyek adalah keterlambatan penyelesaian dan status proyek yang tidak jelas hingga saat ini. Untuk memperoleh data yang akan digunakan dalam evaluasi, dilakukan wawancara (langsung pada manajer proyek) dan observasi serta dokumentasi yang dilakukan dengan cara datang ke divisi IT perusahaan. Sedangkan aspek-aspek dalam manajemen proyek yang akan dievaluasi adalah aspek perencanaan proyek, yang terdiri dari ruang lingkup perencanaan, analisis dan penentuan risiko proyek, sumber daya proyek, pengontrolan proyek, perencanaan kualitas proyek, dan aspek penjadwalan proyek.

Ruang lingkup perencanaan proyek adalah tidak adanya ketegasan dan ketetapan dalam penentuan ruang lingkup pada saat awal perencanaan proyek. Tidak jelasnya ruang lingkup pada awal perencanaan proyek dapat mengakibatkan hal-hal yang dapat menghambat keberhasilan proyek, contohnya arah tujuan pelaksanaan proyek tidak jelas, kebutuhan semakin tidak jelas pada saat di tengah-tengah pelaksanaan proyek, bentuk dari hasil proyek tidak seperti yang direncanakan, dan tidak dapat membedakan antara apa yang menjadi kebutuhan dan apa yang yang hanya menjadi keinginan/kemauan dalam proyek.

Hal-hal yang dapat terjadi tanpa adanya analisis risiko proyek di perencanaan awal, yaitu (1) Pelaksanaan proyek dapat terhambat karena apabila ada risiko yang muncul, maka seorang manajer proyek harus menanggulangi risiko tersebut terlebih dahulu sebelum melangkah ke tahap berikutnya dalam proyek; dan (2) Penundaan pelaksanaan proyek karena tidak adanya analisis risiko pada tahap perencanaan tidak hanya mengakibatkan pelaksanaan proyek terhambat, bahkan dapat mengakibatkan suatu proyek tertunda pelaksanaannya.

Dari hasil wawancara dengan manajer proyek, maka disimpulkan adanya beberapa risiko yang muncul pada saat awal pelaksanaan hingga saat wawancara dilaksanakan. Risiko-risiko tersebut antara lain low komitmen dari pihakpihak yang terkait dengan proyek, tidak adanya transfer knowledge, dan terbatasnya sumber daya manusia. Hal yang paling dapat dijadikan penyebab mundurnya proyek adalah kurang detailnya struktur tim proyek, pembagian tugas, dan penetapan orang-orang yang bertanggung jawab dalam proyek tidak diuraikan dengan jelas.

Evaluasi pengontrolan proyek dilakukan penulis pada hal-hal seperti (1) Pengontrolan biaya proyek, di mana proyek tidak membuat daftar anggaran biaya proyek secara rinci pada awal perencanaan. Manajer proyek hanya menganggarkan biaya maksimal untuk penggunaan outsource agar dapat dijadikan pedoman dalam memilih outsource;
(2) Pengontrolan status proyek, di mana proyek, dari segi pengontrolan status proyek sangat kurang, yang mengetahui status proyek hanyalah manajer proyek; (3) Pengontrolan pelaporan kinerja proyek, di mana dari hasil evaluasi penulis, hal mengenai pengontrolan pelaporan kinerja proyek dapat terjadi seperti itu dikarenakan tidak jelasnya struktural tanggung jawab yang tidak jelas sehingga manajer proyek harus menyusun semua laporan kinerja proyek sendiri.

Pada proyek , perencanaan kualitas sangatlah kurang. Tidak adanya review setelah setiap pekerjaan selesai dilakukan merupakan salah satu pengontrolan kualitas proyek. Dapat disimpulkan bahwa pembuatan WBS (Work Breakdown Structure) sebagai salah satu alternatif tradisional mengorganisasikan proyek menjadi struktur pelaporan hierarkis. Alasannya adalah karena WBS menampilkan tiaptiap fase pekerjaan proyek hingga yang terkecil sehingga manajer proyek dapat menyusun ringkasan informasi untuk perincian tiap-tiap pekerjaan, walaupun pembuatan WBS memakan waktu. Namun, dengan adanya WBS, manajer proyek dapat memperkirakan jadwal proyek dan memeriksa kemajuan proyek. Berdasarkan WBS yang telah disusun, maka manajer proyek menuangkan WBS tersebut ke dalam Gantt Chart dengan bantuan Microsoft Project agar lebih mudah dibaca.

Usulan yang dikemukakan pada penelitian ini adalah usulan untuk closing (penutupan) proyek. Berdasarkan hasil evaluasi, proyek tersebut telah mengalami keterlambatan dan penambahan biaya hingga sekarang, tanpa adanya status proyek yang jelas. Sistematika usulan hanya dibatasi dalam 2 ruang lingkup, yaitu (1) Usulan perencanaan proyek seperti ruang lingkup perencanaan proyek, analisis dan penentuan risiko proyek (Tabel 1), sumber daya proyek, pengontrolan proyek, dan pengontrolan kualitas proyek; (2) Usulan penjadwalan proyek seperti WBS (Work Breakdown Structure) dan Gantt Chart (dengan menggunakan Microsoft Project, dilampirkan). Adapun usulan penulis adalah sebagai berikut. Ruang lingkup akan dibatasi pada tahap ini. Manajer proyek memegang peranan penting dalam tahap ini, manajer proyek harus menentukan ruang lingkup proyek sebatas dengan lingkup penyelesaian proyek, dengan catatan proyek tidak dimulai dari awal jadi meneruskan proyek yang telah berjalan. Manajer proyek mendaftar apa-apa saja yang akan menjadi risiko proyek. Pada tahap ini, seorang manajer proyek dapat membahas dengan tim proyek.

Tabel 1 Analisis dan Penentuan Risiko Proyek (dalam Bentuk Usulan)

\begin{tabular}{clll}
\hline $\begin{array}{c}\text { No } \\
\text { Risiko }\end{array}$ & \multicolumn{1}{c}{ Risiko } & \multicolumn{1}{c}{ Pencegahan } & Penanggulangan \\
\hline & $\begin{array}{l}\text { Sumber daya } \\
\text { Manusia } \\
\text { belum } \\
\text { tersedia }\end{array}$ & $\begin{array}{l}\text { Mengadakan } \\
\text { rencana recruitment } \\
\text { karyawan sebelum } \\
\text { perencanaan } \\
\text { penutupan }\end{array}$ & $\begin{array}{l}\text { Menambah jumlah } \\
\text { outsource dari } \\
\text { pihak developer }\end{array}$ \\
& $\begin{array}{l}\text { Kurangnya } \\
\text { kekompakan } \\
\text { tim }\end{array}$ & $\begin{array}{l}\text { Mengadakan } \\
\text { fellowship }\end{array}$ & $\begin{array}{l}\text { Mengadakan } \\
\text { pendekatan } \\
\text { personal }\end{array}$ \\
& $\begin{array}{l}\text { Waktu } \\
\text { penyelesaian } \\
\text { proyek } \\
\text { diundur lagi }\end{array}$ & $\begin{array}{l}\text { Melakukan } \\
\text { pembuatan } \\
\text { gantchart yang } \\
\text { terinci }\end{array}$ & $\begin{array}{l}\text { Mengalihkan } \\
\text { keseluruhan proyek } \\
\text { ke developer }\end{array}$ \\
\hline 003 & & & \\
\hline
\end{tabular}

Manajer proyek menyusun struktur tim proyek yang baru, kemudian membahasnya di dalam rapat antara stakeholder proyek. Adapun rancangan struktur yang diusulkan dapat dilihat pada Gambar 2.

Pengontrolan proyek dilakukan dengan 3 cara, yaitu (1) Pengontrolan biaya. Usulan berupa masukan agar 


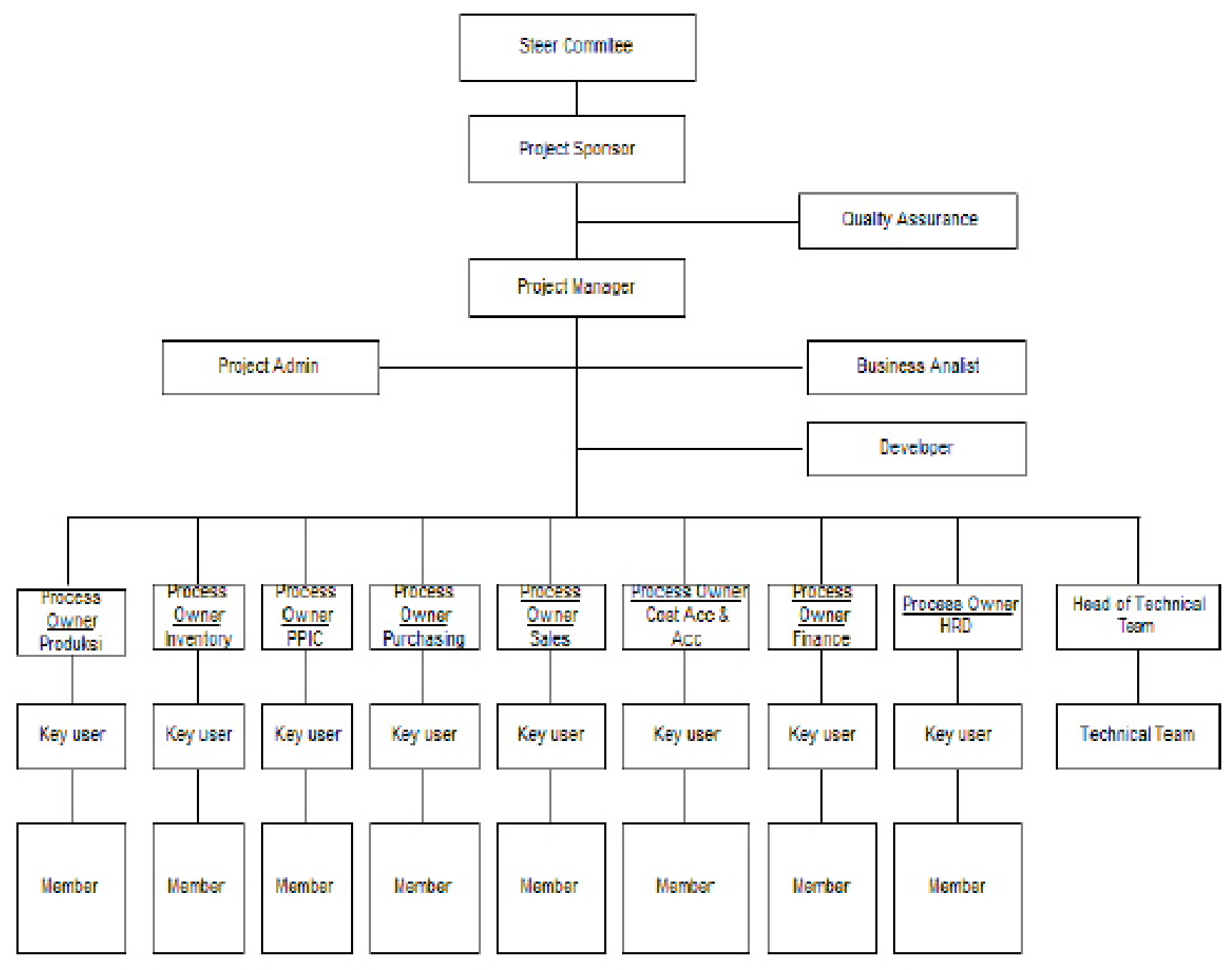

Gambar 2 Usulan Struktur Tim Proyek

biaya proyek ditangani oleh satu orang yang ditunjuk oleh manajer proyek, misalnya project admin; (2) Pengontrolan status proyek, dengan cara mengadakan rapat secara berkesinambungan seperti weekly meeting, evaluation meeting, dan monthly meeting; (3) Pengontrolan pelaporan kinerja proyek dilakukan dengan 2 cara, yaitu perencanaan komunikasi proyek dan dokumentasi pelaksanaan proyek.

Manajer proyek menetapkan pengontrolan kualitas proyek dari awal perencanaan proyek. Pengontrolan kualitas proyek akan dilakukan oleh Quality Assurance. Penutupan proyek akan dilaksanakan sebagai berikut. Penutupan komunikasi dengan mengadakan rapat penutupan tim proyek secara keseluruhan dan mengadakan evaluasi dari awal sampai akhir proyek dilaksanakan, penutupan proyek dengan mengadakan penandatanganan kontrak selesai antara manajer proyek dan developer dan mengadakan penandatanganan kontrak selesai antara manajer proyek, Steer Comitte dan Project Sponsor.

\section{SIMPULAN}

Adapun hasil yang diperoleh setelah melakukan evaluasi pada manajemen proyek adalah sebagai berikut. Proyek dimulai pada bulan Maret 2005, direncanakan selesai pada bulan Januari 2007. Sampai saat ini status proyek masih 90\%, kekurangan terdapat pada kegiatan data mapping dan data migrasi. Proyek mengalami kemunduran selama satu tahun lebih. Rencana awal selesai pada bulan Maret 2005, namun mundur hingga Februari 2006 dan hingga sekarang proyek yang ditangani oleh 2 pihak memiliki risiko gagal yang lebih tinggi dibandingkan dengan proyek yang ditangani oleh satu pihak. Salah satu penyebab kemunduran proyek yang dilaksanakan oleh perusahaan adalah penanganan risiko yang kurang terencana dengan baik, dan permintaan kebutuhan akan sistem dari user yang tidak ada batasnya menyebabkan penambahan waktu dan biaya. Hal ini juga menyebabkan ketidakjelasan mana yang menjadi kebutuhan dan yang menjadi keingina serta tidak adanya penjadwalan terhadap perencanaan penutupan proyek. Hal ini mengakibatkan proyek yang telah dilaksanakan mengalami kemunduran dan membutuhkan biaya tambahan.

\section{DAFTAR PUSTAKA}

Chan, K.C., Ong, P., and Indrajit, R.E. (2004). Integrated project management, Yogyakarta: ANDI.

PMBOK Guide. (2000). A guide to the project management body of knowledge. Project Management Institute.

Santosa, B. (2003). Manajemen proyek, Surabaya: Guna Widya.

Schwalbe, K. (2004). Information technology project management, edisi ketiga, Cambridge: Course Technology. 